\title{
Perceptions of the Use of the Word "Feel" in the Workplace
}

\author{
Kelly Doell ${ }^{1}$ \\ ${ }^{1}$ Department of Population Health, University of Ottawa, Canada \\ Correspondence: Kelly Doell, Department of Population Health, University of Ottawa, Ottawa Ontario, Canada. \\ Tel: 613-562-5691. E-mail: kdoell018@uottawa.ca
}

Received: April 1, 2013 Accepted: May 2, 2013 Online Published: May 17, 2013

doi:10.5539/ijel.v3n3p1 URL: http://dx.doi.org/10.5539/ijel.v3n3p1

\begin{abstract}
This study explored attitudes toward the deployment of the word feel in workplace communication. A discourse analysis of this emotionally declarative word across three types of workplace relationships revealed a set of social rules guiding how emotional self-disclosure is managed. Participants outlined how resistance to these rules put social or professional capital at risk but it was deemed necessary in order to maintain or restore equilibrium between well-being and job performance. Although status stratification in the workplace functions to maintain productivity, participants revealed an ongoing tension between performance and authentic emotional expression. The effects of this tension, examined through beliefs about of the word feel, are discussed for its role in workplace well-being.
\end{abstract}

Keywords: well-being, workplace, self-disclosure, feel, emotion

\section{Introduction}

\subsection{Introduction}

Professionalism has been described as a value system within which new workers learn the social order of things in the workplace, preserve this order, and stabilize it (Evetts, 2003). Once exposed to this order, an employee's behaviour mostly becomes self-governed, keeping him or her disciplined to a set of social rules (Foucault, Martin, Gutman, \& Hutton, 1988). Moreover, professionalism and emotional behavior have a particularly unique relationship whereby "professionalism refers to a blend of expressed and suppressed emotions that still allow a person to be considered "professional" in their workplace role" (Lively, 2000, p. 38) and although the prevailing ideology has been that emotions are irrational and unproductive in workplace environments (Putnam \& Mumby, 1993), the workplace is still saturated with emotional experiences. This presents a tension between maintaining a rational-professional role and acting emotionally authentic (Ashforth \& Humphrey, 1995; Basch \& Fisher, 2000; Boudens, 2005). Recently, emotional discourses, such as the emergence of emotional intelligence, have gained legitimacy as a positive component of leadership and workplace performance (Hughes, 2005; Kramer \& Hess, 2002; Gibson, 2006; Tracy, 2000). However, organizational settings rarely elicit complete authentic expression, but require, instead, different forms of emotional management (Fournier, 1999). Emotional management is not just directed at emotional display but penetrates verbal communication through adjustments in language choices (Cameron, 1995; Coupland, Brown, Daniels, \& Humphreys, 2008). Interestingly, a vast amount of research on emotional management in the workplace has concentrated on emotional display with less of the focus set on verbal acts of emotional self-disclosure (Dougherty \& Drumheller, 2006; Kramer \& Hess, 2002; Trethewey, 1997; Waldron \& Krone, 1991). Furthermore, few studies have examined the management of the verbal mechanisms of emotional self-disclosure in these settings. None have analyzed mechanisms of emotional disclosure governing the use of the word feel. As such, the purpose of this study was to explore perceptions of the use of the word feel in workplace communication. Since the need to share emotions has been considered ubiquitous and pervasive (Rimé, Corsini, \& Herbette, 2002), understanding how these mechanisms of verbal emotional disclosure are perceived may introduce new prospective leverage points for nurturing workplace well-being.

\subsection{Background Literature}

This section reviews emotional disclosure from three perspectives. First, the link between emotional expression and well-being will be considered. Next, the relationship between power, context, and the verbal disclosure of emotions will be reviewed. Finally, the role of language in emotional self-disclosure will be established, 
introducing this study's particular interest in the word feel as a unique focal point for examining emotional communication.

\subsubsection{Emotional Expression and the Workplace}

In general, the freedom to express private feelings has been shown to have positive effect on health and well-being (Ferrara, 2002; Kooiman, 1997; Pennebaker, Zech, \& Rime 2001; Sriram, Chaturvedi, Gopinath, \& Shanmugam, 1987; Taylor, Bagby \& Parker, 1997). However, the workplace has historically enabled cognitive rather than emotional expression even though emotions are still felt in this context (Collins, 1990). As a result, employees can display emotions that are incongruent with how they actually feel. As useful as this emotional labor may be for organizations, the resultant dissonance it creates for employees can have harmful consequences to employee well-being and performance (Dilorio \& Nusbaumer, 1993; Erickson \& Wharton, 1997; Shields, 2005; Wharton \& Erikson, 1993). Burnout, exhaustion, and low job satisfaction have been identified as just a few of the negative outcomes (Côté \& Morgan, 2002; Cropanzano, Weiss \& Elias, 2003; Grandey, 2008; Rafaeli \& Sutton, 1989; Zapf, 2002). Similarly, research on emotional behavior has revealed that emotional suppression, the conscious withholding of inner feelings, can cause a series of harmful effects including decreased enjoyment, decreased stamina, increased anxiety, and even increases in depression (Erickson \& Wharton, 1997; Gross, 2002; Gross \& Levenson, 1997; Muraven, Tice, \& Baumeister, 1998). In certain instances, these negative effects may be experienced in sacrifice for the maintenance of the rational-professional discourse.

The workplace has been of interest for communication researchers partly because its hierarchical social structures set a foundation for emotional experiences by creating subordinated roles (Shils, 1970; Tiedens, 2001). However, individuals still draw upon their own discretion for what and how much they emotionally reveal (Ekman, 1993; Erickson \& Wharton, 1997; Hochschild, 1983). Foucault (1979) noted that professional discourses mean that people are required to be self-controlled and self-motivated to perform in ways the organization defines as appropriate. As a result, individuals who achieve these targets "will be rewarded with career promotion and progress." (p. 408). Shields (2005) elaborated that successful workplace interaction can be defined by how an employee navigates these workplace politics, including the codes that dictate who has the freedom to emotionally self-disclose, what a person can be emotional about, and under what circumstances. In general, professionalism demands a balance of expression and suppression that still allows the maintenance of a person's professional identity amidst their colleagues (Farrell \& Geist-Martin, 2005; Lively, 2000; Van Maanen $\&$ Kunda, 1989) and even with customers (Hood \& Forey, 2008). The workplace requires a form of emotionally communicative competency including the skillful use of self-disclosing language (Cameron, 1995; Coupland et al., 2008). Martin and White (2005) noted how this aptitude is what helps people align themselves with the shared beliefs and values of communities.

Status hierarchies (i.e., lines of authority or supervision) in workplace communities mean that the freedom to be emotionally authentic in the workplace is not experienced by all (Allendar, Colquhoun, \& Kelly, 2006; Lee \& Jablin, 1995; Sandelands \& Boudens, 2000). The tendency for unequal emotional communication is common and is one effect of power in interpersonal communication (Foucault, 1988). There are different rules for emotional acceptability based on status. Subordinates, for example, are expected to suppress anger in the workplace as this emotion is typically reserved for those in higher level status positions (Pearson, Anderson, \& Porath, 2000). Kramer and Hess's (2002) survey research revealed several discursive rules for sharing emotions in workplace including that, 1) emotions are to be expressed professionally, 2) emotions are expressed to improve situations, 3) emotions are expressed only to the right people, 4) emotions are allowed to help individuals, and, 5) emotions are not to be managed to the detriment of others. Rules such as these catalyze a host of self-management techniques (Eckman, 1972).

Since employees are subjects of multiple discourses in their lives (i.e., father, friend, or professional) following the rules of one discourse may consciously or unconsciously produce resistance to the rules of another. In all accounts, individuals can, potentially but not necessarily, be produced as self-aware, emotional subjects in competing discourses that carry contradicting rules which ultimately generate psychological tension. Language is at the heart of this tension.

\subsubsection{The Language of Emotional Disclosure}

According to Pennebaker, Mehl, and Niederhoffer (2003), emotionally expressive cues begin with words. Moreover, Lupton (1994) described that, "language does not exist in a social vacuum but is embedded in social and political settings and used for certain purposes" (pp. 17-18). Bolton (2000) also proclaimed that "language is a type of social performance led by rules which match what someone feels with the situation they are in. Language is a vehicle for criss-crossing the often invisible boundaries between the public and private worlds" (p. 
160-161). Since language is the symbolic representation of thoughts, beliefs, and feelings, it has a vital role in emotional self-disclosure and the production of discourse. Yet, past research has tended to focus on the general act of emotional disclosure or its attached emotional content (i.e., sadness, happiness, or anger) and less on its linguistic mechanics.

The choice of language use in self-disclosure can reveal a lot about the nature of subjectivity and the effects of power in the workplace. For instance, in an examination of written communication in the workplace (e.g., memos, reports), Forey (2009) outlined that verbal projections act to define the speaker certain ways, including their workplace position relative to their intended audience and, in places, the degree to which they assume responsibility over what they are writing. For example, the grammatical choice of it is believed that softens responsibility over the message that follows more than I believe that. The former creates a distance between what is said and the writer while the latter is more personally disclosing. Forey (2009) suggested that these choices are not made randomly in the workplace but consciously to a certain degree.

These types of linguistic components of self-disclosure are valuable for understanding the connection between certain social practices and health process or outcomes (Viswanathan, 2008) and how people align themselves within discourse to achieve a sense of belongingness or social acceptance through their language choices (Martin, 2004; Martin \& White, 2005). While several studies or reviews have discussed the relationship between emotion and language (Barrett, Linquist, \& Gendron, 2007; Coupland et al., 2008; Majid, 2012) no studies have made $f e e l$ its primary focus of analysis as a mechanism for self-disclosure. The word feel, according to Fiehler (2002), is a thematic expression, described as a word that designates events or experiences. More specifically, experiential declarative expressions, "define what occurs in their scope as experience or emotion" (p. 88). An authentic declarative expression, therefore, casts light into private, inner experiences. In certain forms (e.g., I feel) the word feel represents a disclosing speech act with closer association to inner emotional experiences than other more cognitively symbolic representatives like the words think or believe (Fiehler, 2002; Mayer \& Tormala, 2010). In fact, Mayer \& Tormala (2010) determined that feel and think leave distinctly different impressions on the listener. Due to its emotional connotation, it is presumed that feel does not align itself with the rational-professional discourse.

\subsection{Research Aims}

Foucault (1972) emphasized that verbal statements have a role beyond linguistic analysis including the ability to expose effects of power by enabling, "rules or forms to become manifest" (p. 99). This study aimed to explore the discursive rules for the word feel by examining employee perceptions of its management in workplace relationships of differing status. This analysis sought to answer three specific questions. First, how do participants make sense of the word feel? Secondly, how do people perceive to use the word feel in their workplace relationships? Finally, what does their perceived management of the word feel reveal about relationship between productivity, well-being, and professionalism? By examining these questions, an analysis of the effects of power on emotional self-disclosure in this common setting is made possible (Willig, 2004).

\section{Method}

\subsection{Design}

The purpose of this study was conducive to qualitative methods and discourse analysis (Willig, 2004). Qualitative methods are typically well-suited for exploratory social research (Denzin \& Lincoln, 2011; Stebbins, 2001) while discourse analysis attends to language to identify effects of power on social life (Fairclough, 2001; Willig, 2004).

\subsection{Participant Characteristics}

Fifteen participants were interviewed for this study (see Table 1). All participants were Caucasian, 9 of the 15 were female, ranging in age from 19-76 with an average age of 36.0 years. 
Table 1. Participant characteristics

\begin{tabular}{lcll}
\hline Participant & Age/Gender & \multicolumn{1}{c}{ Profession } & \multicolumn{1}{c}{ Relationship Status } \\
\hline Juliette & 25/F & Nursing Student & Unmarried, dating \\
Theresa & $32 / \mathrm{F}$ & Civil Servant & Unmarried, dating \\
Jerry & $31 / \mathrm{M}$ & Civil Servant & Married with children \\
Paul & $46 / \mathrm{M}$ & Ecologist & Divorced with children \\
Ben & $47 / \mathrm{M}$ & Call Center Operator & Married with children \\
Cindy & $29 / \mathrm{F}$ & Pharmacist & Married with children \\
Nancy & $33 / \mathrm{F}$ & Mental Health Worker & Unmarried \\
Jennifer & 26/F & Civil Servant & Unmarried \\
Jake & 29/M & Military Officer & Unmarried, dating \\
Olivia & $33 / \mathrm{F}$ & Engineer & Married \\
Brenda & 40/F & Office Manager & Married with children \\
Nadia & $31 / \mathrm{F}$ & Office Administration & Unmarried \\
Charles & $43 / \mathrm{M}$ & Program Manager & Married with children \\
Christine & $19 / \mathrm{F}$ & Education Student & Unmarried \\
Alexander & $76 / \mathrm{M}$ & Retired - Military & Widow with children and \\
& & & grandchildren
\end{tabular}

\subsection{Sampling, Procedure, and Materials}

Participants responded to an advertisement describing a study on feel at a campus health services centre. Those who showed interest were invited to contact the researcher via telephone or email. Upon doing so, an interview was scheduled to take place on the university campus where an opportunity was given to review the information about the study. Audio-recorded interviews commenced after participants signed an informed consent form. Materials for data collection included an interview guide (Table 2), information sheet, and informed consent form. These materials were approved in advance by the University Ethics Review Board.

\subsection{The Interview}

Interviews ranged from 60 to 120 minutes each and focused on the meanings participants associated with the word feel and how they used this word across three common hierarchal relationships in the workplace including with superiors, subordinates, and with colleagues. The interview began with a projective exercise whereby participants were asked to share the first mental image they associated with the word feel and, afterward, to explain their responses. Projective questions such as these are designed to evoke constructions of meaning and eliminate research assumption (Soley \& Smith, 2008). Questions from the interview guide were supplemented by probing questions that were used to clarify responses, request further information, or invoke elaboration (Rubin \& Rubin, 2005).

Table 2. Interview guide

\begin{tabular}{llll}
\hline \multicolumn{1}{c}{ Part One } & \multicolumn{1}{c}{ Part Three } & \multicolumn{1}{c}{ Part Four } \\
\hline & & & \\
Q1. What images, if & Q2. How, if at all, & Q3. How, if at all, do you use & Q4. What other thoughts \\
any, come to mind do you use the the word feel with: & $\begin{array}{l}\text { would you like to add } \\
\text { about your use of the word } \\
\text { when you think of the word feel in your } \\
\text { word feel? }\end{array}$ \\
& daily life? & Superiors & feel? \\
& & - Subordinates & \\
\hline
\end{tabular}

\subsection{Post-Interview}

Study debriefs were sent via email to each participant along with a transcription of their interview. An invitation was made to make changes to the transcripts prior to analysis. No changes were requested. 


\section{Analysis}

\subsection{Overview of Discourse Analysis}

Since an analysis of language allows for the interpretation of social life (van Djik, 2001), discourse analysis was selected for this study. Discourse analysis was used to identify clusters of themes, ideas, and images shared by participants that acted to unveil the rules that governed their perceived use of the word feel operating below their conscious awareness (Fairclough, 2001; Lupton, 1992; Potter \& Wetherell, 1987). Discourse analysis also considers power in its explanation of discursive practices of subjects (Fairclough, 2001). As a result, analyses concentrated on (a) the social and discursive functions of the word feel in the workplace, (b) the rules systems regarding the "appropriate" use of the word feel in the workplace and, (c) how these rules were resisted (Harré, 1986).

\subsection{Data Organization}

Analysis of each transcript started with a thorough reading of the interview text and identifying statements pertaining to the eight targeted relationships. The analytical steps included preparing the transcripts, creating meaning units from the data and tagging them, creating data categories, and categorizing the meaning units under relationships (Côté, Salmela, Baria, Russell, \& Storm, 1993). Themes were subsequently identified within and across participant beliefs about the use of the word feel in their relationships. Like themes were then grouped together while alternative cases were also recognized and evaluated for their relevance including their role in framing resistance to the discursive rules for the word feel (Willig, 2004; Wood \& Kroger, 2000).

\section{Findings}

This section presents the findings from the interviews on the topic of the word feel. It includes how participants constructed the meaning of the word feel, their perceived use of the word feel across common workplace relationships, and how participants linked the use of the word feel to well-being in the workplace. In preparation, one participant, Brenda, summarized the general rule for the use of feel in the workplace setting:

I wouldn't use it (at work). Maybe it is just my level of understanding of the system and how it works. At this point I feel I have to be ultimately professional and not use it. Let's just think about action items that are going to get us where we have to go. You try to depersonalize the process. (Brenda)

Brenda's description introduced several themes present in many other accounts by other participants. This included how others constructed its meaning in this context.

\subsection{Constructions of the Word Feel}

\subsubsection{The Word Feel Does Not Belong in the Workplace}

Unanimously, each participant's initial responses about using the word feel in the workplace showed hesitation and caution. In subsequent reflection, specific conditions for its use emerged. For example, Theresa, a civil servant, said feel belonged only in her private life, identifying the difference in rules between these two contexts:

At home, you're going to have intimacy right? There are certain rules at work. At home you don't have them. You can voice things differently at home where you couldn't at work in terms of how you feel. You're not going to go down that road at work. (Theresa)

Although Theresa alluded to an absence of rules at home, the rules governing the use of 'feel' in this personal milieu are simply different. Consistent with the work of Foucault (1979), her perspective was prevalent among other participants as they spoke about self-managing their emotional behavior at work. For example, Charles introduced the relationship between context and professional risk:

For people to freely express how they feel about something, be it personal or professional, it has to be a little like how we find ourselves right now. This (setting) is more personal. There aren't any other people around that might pose a threat. There aren't any competitors anywhere. In a work environment, at the end of the day, you're looking to progress within the organization (...) the people around the table, colleagues and friends, are also potential competitors. (Charles)

Foucault et al. (1988) stressed that people who behave appropriately and according to certain codes get rewarded with progress in professional settings. Charles expressed the idea that his feel-based language influences his success at work. These two excerpts described two chief perceptions. First, the word feel is unprofessional and, second, the use of the word feel is intimate and personal. Interestingly, as reflection continued, hesitation emerged as participants recalled exceptions to these perspectives. 


\subsubsection{The Word Feel Is Unprofessional Because Feel Is Seen as Personal}

Kramer and Hess (2002) found that professionalism, after job competence, was defined as keeping one's private life separated from the workplace and leaving emotions out of interactions with colleagues. In the opening quote to this section, Brenda, an office manager, captured this sentiment as she attempted to keep the workplace impersonal and unemotional even in the way she manages the word feel. She referred to a standard of behavior that kept the use of the word out of the workplace. Most participants cited the use of the word feel as being an intimate form of interpersonal communication. "Personal", in these cases, referred to inner feelings typically reserved for close relationships and private times or places. The word feel appeared to put the professional discourse in competition with the private where feelings are more openly communicated.

As a result, Nadia, an office administrator, rejected the word feel in the workplace. She referred to the word feel as being too "emotional", a quality that does not fit professional settings:

The word feel doesn't jive with the professional context. It brings in an emotional factor and it makes me feel like I'm not being professional. So somebody that I don't feel open enough to share how I'm feeling I probably wouldn't use the word feel. I would say... I don't know what I'd say. I sense that I probably haven't or don't use it with someone I'm not close to or don't trust. (Nadia)

Similarly, Nancy, a mental health worker, also felt that discretion in the use of the word feel was imperative in her job. However, citing the demands of the professional discourse, she illustrated a desire for having freer use of the word feel in the workplace.

I have been brought up that you don't show things like that in the work environment. You have to be professional and capable. You don't give people anything else. For me it is a balance. Part of me wants to go the other way though. It is a conflict. (Nancy)

Nancy referred to a struggle between her upbringing, the demands of the workplace, and the need to authentically express herself. Her thoughts revealed that the use of the word feel could threaten perceptions of her ability to perform at her job but, at the same time, its use demands that she make concessions. Several participants shared the sentiment that they felt they could be judged poorly for using feel at work. Nancy felt required to manage her feel-based language in a way that may compromise her true self in order to avoid judgments. This account represents the type of dissonance that can have implications for health and wellness (Shields, 2005; Wharton \& Erikson, 1993; Erikson \& Wharton, 1997).

\subsubsection{The Word Feel Is Emotional}

The hesitation with which each participant shared in using the word feel in the workplace was tied to the emotional connotation of the word. Nadia, along with eleven others, identified a link between emotions and feel:

I guess the images I would have of the word feel would be of extreme feelings of either extreme sadness or extreme joy in a certain moment, of me feeling those things. That probably would be the image that comes to mind for that word. (Nadia)

The prevalence of this connection suggests that the rational discourse is dominant. Participants typically revealed a need to be cautious in their use of feel. Some identified that using the word could pose a social or professional risk to their reputation in the workplace. Nadia, in response, represented this sentiment as follows:

I don't want to be viewed as someone who is overly emotional but someone who has a grasp on things. I am not inclined to use the word feel at work (...) It would probably be viewed as a weakness like I'm not tough skinned or can't handle stress or conflicts. (Nadia)

Nadia's concern about her professional image was shared by four others. To address this concern, Jerry, for example managed feel by strategically replacing it with think. He believed that this helped him escape judgement:

When it is something I'm not too confident in, when it is something I feel I need to project more intelligently or more respectfully, I will use think. Where I work now, they don't care what you feel. They want to know what you think and the thought behind it. "I feel" is a tentative, less confident way. (Jerry)

The replacement of the word feel with think represented a more conscious or strategic attempt to align themselves with the professional discourse. Although it may be difficult to conclude that those who did not behave reflexively in this way are docile (i.e., unconsciously disciplined) (Foucault, 1988), it is fair to say that some participants never considered their use of the word feel in the workplace prior to these interviews. The reasoning behind Jerry's adjustment suggests that think is an effect of power. In all, replacing feel with think 
seemed to be a way to skirt negative judgement, like being too personal or weak, which could threaten their professional advancement. This type of language choice might be an attempt to cloak an actual feeling as opposed to reveal a thought as a way to impersonalize the disclosure.

\subsubsection{Feel as Point of Emphasis}

As reflection continued, contradictory examples of the word feel actually being used accumulated. Despite describing its stigmas, participants shared instances where they would consciously use the word feel to emphasize certain messages in certain situations. In these occasions, feel served as a sincere declaration. Jennifer and Theresa represented these perspectives respectively:

I may use it when I'm in a meeting and I have a point of view. When it's your turn to talk at the table and you want to express something important you normally start off by saying "I feel" this way. That's how I'd use it at work. (Theresa)

I would use it in terms of something I meant sincerely like "I feel that we should take this course of action" under a certain scenario. If I felt very strongly about it or it was part of something I thought was really important, I would use it. (Jennifer)

For some participants, the word feel commanded special attention, conveying an increase in the importance of their message as if it was symbolic of honesty. As a result, the expectation was to be taken seriously. Provided how several participants alluded to the word feel being risky, it was not surprising that feel was given an emotional meaning.

The above shows that the general rule for the workplace was that the word feel was inappropriate. The tendency to honour this rule was exemplified, on one side, through replacing feel with think. However, further reflection revealed that the majority of participants contradicted themselves by reporting its use for making important points. Foucault (1982) identified that discourses are in regular competition with one another so it could be expected that participants would identify moments where they remembered using it even though they believed it was unwelcome. As additional analyses explain, competing discourses make managing the word feel more complex than participants initially considered.

\subsection{Using the Word Feel Across Workplace Relationships}

Each participant was asked to describe how they perceived the role that the word feel had in their communication with their colleagues, subordinates, and superiors. Their accounts illustrated that the workplace setting was not a monolithic site, but a more complex environment that contained both professional relationships and more personal ones that influenced perceived self-disclosing language choices.

\subsection{1 'Feel' with Superiors}

Each participant had at least one person at work to whom they were professionally accountable. Their bosses were people who had the power to terminate their employment, to delegate work, and offer judgements pertaining to job performance. The strongest hesitation toward the use of the word feel came in these relationships. Nancy suggested the word feel had no place in communication with her supervisor:

My boss is a pretty busy person so I am not going to use it with her. Sometimes I have wondered if that was harming me or I wonder if I should just take the chance and see what happens and have enough trust. (Nancy)

Interestingly, Nancy perceived that there could be benefits to successfully introducing it into her relationship with her supervisor. Trust had been a key factor in her hesitation. As the norm, self-disclosing using the word feel with superiors was perceived as best avoided.

Meanwhile, Juliette, a civil servant, noted that she had used the word previously with her boss in her performance review. Even when breaking the feel rules, she reinforced that it is reserved for exceptional circumstances:

The word would have to refer to what I've accomplished or how I feel my progress is going. It would be in reference to goals and your relationship with people. You don't say to your boss I feel frustrated with you because you don't pay attention or you don't care. (Juliette)

Juliette was not alone. Nadia also shared her resistance, revealing that it came as a result of competing discourses:

Well, with my boss, I feel like I have a friendship with her. So it is kind of different. I would use it... I trust that because I am telling her how I'm feeling that it won't skew her professional perception of me. (Nadia) 
Competing discourses hold people in positions to make choices on how to manage their behavior (Foucault, 1982; 1988). The above examples support how the more personal role of being a friend and the role of being professional can oppose one another. Several others portrayed a freer use of the word feel with colleagues whom they consider friends. Trust and friendship may negate these effects of power in the workplace.

Although feel was considered unwelcomed, it lost its stigma if it was used in reference to job performance or productivity with a superior. Ben highlighted how the word would be used during his performance reviews with his superior:

With your boss, I think the word feel could be used in a professional context. If you are going through your yearly evaluation you could use the word feel or "I felt like". But I am not sure it would feel okay to use it in everyday exchanges with a superior. (Ben)

Disclosing feelings with the boss was frowned upon yet almost expected when it pertained to discussion of one's work performance. While participants reported that they would not voluntarily use the word, they showed instances where it emerged because a supervisor wanted more information. In the workplace, there is an expectation that private, emotional information is available to those in more powerful status positions.

\subsection{2 'Feel' with Subordinates}

In total, five participants held supervisory roles. When workplace roles were reversed, participants shared differing attitudes towards the use of the word feel. As Jake described, the word feel was approached much differently by those with decision-making authority over others:

Actually, I ask my subordinates a lot about how they feel. Generally, if they're feeling good, they're going to produce a lot more. So I generally want them feeling good. I want to send them in a direction where they're feeling good. So I often ask them how they're feeling. (Jake)

Those in supervisory status positions appeared to convey an attitude to entitlement in accessing the feelings of subordinates because of the connectivity of emotions and performance. While subordinates felt unable to inquire using the word feel, supervisors conveyed less constraint over its use in this way. However, supervisors noted that they would not disclose to someone of lower status unless the relationship was more personal in nature. Nancy outlined that she will introduce it with a co-worker if they choose a harmless context outside of the workplace:

If it is a side time from work and talking to someone on a more personal level, I would. I probably would do it with someone I am comfortable with or who I trust or who trusts me and it is reciprocated. It would only come up with someone with whom I had a rapport like with a friend or if a staff member comes to me with problems. Sometimes, people feel comfortable coming to talk to me so that word might come up in those circumstances but not in a professional setting. (Nancy)

Nancy's comments were indicative of Foucault's panoptic effect (1979). As if being monitored, Nancy feels the need to assess or change the environment to circumvent the rules. Foucault (1979) elaborated that when power is internalized, subjects can behave in ways to avoid this gaze. He wrote that subjects, "inscribe in (themselves) the power relation in which they simultaneously plays both roles, they becomes the principle of their own subjection" (p. 203). Nancy's behavior reinforced what others have stated about the role of special workplace zones or places in the workplace that allow for emotional authenticity (Fineman, 1993).

Those with higher status (i.e., superiors) appeared free to use the word feel and prompt it from their subordinates. Foucault (1982) asserted that power is productive. It could be argued that in private or personal settings the word feel is construed as an act of care for a friend, for example, but, in the workplace, the dynamics of power supported the use of word feel as a way to monitor and enhance productivity. This supports how employers have incorporated workplace wellness initiatives into workplace culture. If how an employee feels contributes to their performance, it is understandable that corporate wellness programs invest in protecting or strengthening this link. However, these participants were more interested in using feel as a technique of productivity rather than a device for assessing well-being. Employers appear willing to use many methods to this end (DeVries III, 2010).

In general, this word appeared as a type of tool or communication competency that allowed those supervising participants to monitor an employee's process of performance. Interestingly, the five supervisors interviewed explained that they must self-manage their declarations in the face of their own supervisors.

\subsection{3 'Feel' with Colleagues}

Conversations with colleagues yielded a mixture of sentiments about the use of the word feel. Participants described their relationships with some workplace colleagues as merely professional while others relationships 
were more personal. For example, Jennifer expressed her desire to maintain a professional appearance at work:

I don't have a lot of personal attachment to my job. I suppose that if I felt like something was really against what I wanted to do I would say that I felt very strongly about it. But I think I would probably exercise a different word to communicate what I was trying to say because the nature of my work isn't particularly personal. (Jennifer)

Jennifer's description also identified that she may use the word under the appropriate circumstance but, like Jerry and Paul presented earlier, she preferred to strategically avoid it, even consciously choosing to use different words. By contrast, Ben valued his personal connections with colleagues in the workplace:

I would use it differently with someone who I have a personal working relationship and who is at the same level with me at work. I am more inclined to share the details of my personal life with someone who I work closely with. That is my style of working with people. I probably tell them more than they want to know! (Ben)

Lively (2000) found that employees who share similar roles at work tend to participate in similar emotional management with each other. However, social stratification is often maintained by lower status individuals who serve the emotional needs of their superiors (Hochschild, 1983; Pierce, 1995). For Ben, status equality meant less risk in sharing how he felt. Although these relationships are still at risk for negative social or professional judgement by others, the discretion applied appeared lessened. A colleague was deemed less threatening to the professional capital of an individual than a superior. That is, acting unprofessionally through the word feel has fewer consequences with those who do not hold the ability to affect employment. This reinforces the observation made by Forey (2009) that the linguistic devices used in the workplace can be impacted by the relative positions of the individuals in communication.

\subsection{The Word Feel and Well-Being at Work}

Resistance is not unusual in the workplace since discourses and identities are often in competition with one another (Lutgen-Sandvik, 2006; Trethewey, 1997). Well-being played a catalyzing role in the resistance of the feel rules. Suppressing emotions had a limit. Eleven of the fifteen participants referenced an example of using feel with a co-worker with a superior when they had reached a form of psychological distress. Being at this "wits-end" yielded a disregard of any workplace rules related to the word feel. This rupture was characterized by using the word feel openly and honestly to describe challenges or obstacles that have been, by their observation, causing problems. Most importantly, factors such as status, productivity, trust, or context became irrelevant, indicative of a break from the professional discourse they had described.

Nadia, in one example, disclosed how she used feel as a point of emphasis to help resolve a negative issue with colleagues in a group meeting:

I probably would use it to express some sort of anxiety. It's probably more likely in a negative way. Like if co-workers are venting and I'll say, "I feel as though the team is not supporting each other." (Nadia)

Ben shared a similar perspective:

I've used it by saying to my superior "I feel you aren't giving me a fair shake" with getting extra duties I received. (Ben)

Ben and Nadia's descriptions were representative of openness to the word feel when employees were not feeling how they wanted to be feeling. It was reported as being used in groups, one-on-one, with colleagues, and superiors. Feel crossed the boundaries of competing discourses. Christine expressed that the only instance she could ever recall using the word feel at work was in an emotionally poignant moment:

I worked at a diner, the owners were foreign. The way they treat their workers there is different from here. The way they were, everything had to be quick and done. One time they made me cry because they were harsh about it. I was really under stress. I never talked to them that much because they weren't that pleasant. That's the only time I've used the word feel. (Christine)

If a worker felt their well-being was compromised or they had approached their wits end, the word feel became a communication option that transcended status. Participants perceived that when they became too frustrated, stressed, or anxious, a resolution to the tension could be voluntarily sought by self-disclosing through the word feel. The risks inherent to the use of the word feel were ignored. This observation resembled Stile's (1987; 1995) fever model of self-disclosure which purports that disclosure tends to increase as does psychological distress. Disclosure, in this way, serves to relieve tension or stress. In addition, this pattern offers support to Kramer and 
Hess' (2002) finding that emotional expression is more acceptable when its purpose is to remedy a situation.

\section{Conclusion}

The purpose of this research was to explore perceptions of the word feel in workplace communication. The perceived deployment of the word feel by this study's participants appeared contingent on their organizational position in relation to the listener. The cautious attitude toward the use of the word feel was symbolic of a desire to maintain a professional identity through suppressing verbal self-disclosure in this context.

In reference to the research questions of this study, the following conclusions can be drawn from the findings. First, participants constructed the word feel as a personal and unprofessional emotionally disclosing act. Secondly, participants perceived their use of the word feel as potentially risky, influenced by their relative status with co-workers and by trust. In attempts to fulfill occupational status, participants perceived that they managed the word feel carefully in their face-to-face communication, reproducing hierarchies in the process. Finally, the management of the word feel was depicted as a product of the tension between productivity and well-being whereby the professional risks of its use were weighed against the suppression of feelings that the word would help communicate. A rupture in the professional discourse emerged as participants shared that they had used the word feel under psychological duress. In addition, the presence of trust also allowed for the multi-directional use of the word feel (i.e., upward with superiors and downward with subordinates), primarily as a result of the competition between professional and personal discourses. Participants described that trust and friendship strongly buffered the risk assumed in communicating using the word feel.

Overall, the workplace is a complex setting that possesses both professional and personal relationships. A specific analysis of the use of word feel in this context revealed the tension behind emotional communication that, as a result, can influence productivity and employee well-being. A workplace that recognizes the need for safe, equitable opportunities to use feel-based disclosure, free from social or professional risk, may symbolize an emotionally healthy workplace. Therefore, further research should consider exploring the actual effects of using the word feel in the workplace including a focus on the development, repair, or maintenance of trust and well-being.

\section{Acknowledgements}

I would like to thank Dr. Christine Dallaire of the University of Ottawa for her advice and support during the research process and the development of this report.

\section{References}

Allender, S., Colquhoun, D., \& Kelly, P. (2006). Governing the workplace population through workplace health: Knowledge, self and power in workplace health programs. Critical Public Health, 16, 131-142. http://dx.doi.org/10.1080/09581590600828519

Ashforth, B., \& Humphrey, R. (1995). Emotion in the workplace - a reappraisal. Human Relations, 48, 97-125. http://dx.doi.org/10.1177/001872679504800201

Barrett, L. F., Lindquist, K. A., \& Gendron, M. (2007). Language as context for the perception of emotion. Trends in Cognitive Sciences, 11, 327-332. http://dx.doi.org/10.1016/j.tics.2007.06.003

Basch, J., \& Fischer, C. D. (2000). Affective events - emotion matrix: A classification of work events and associated emotions. In N. M. Ashkanasy, C. E. J. Härtel, \& W. Zerbe (Eds.) Emotions in the workplace: Research, theory, and practice (pp. 221-235). Westport, CT: Quorum.

Bolton, S. (2000). Emotion here, emotion there, emotional organizations everywhere. Critical Perspectives on Accounting, 11, 155-171. http://dx.doi.org/10.1006/cpac.1998.0236

Boudens, C. J. (2005). The story of work: A narrative analysis of workplace emotion. Organization Studies, 26, 1285-1306. http://dx.doi.org/10.1177/0170840605055264

Cameron, D. (1995). Verbal Hygiene: The politics of language. London: Routledge.

Collins, R. (1990). Stratification, emotional energy, and the transient emotions. In T. D. Kemper (Ed.), Research agendas in the sociology of emotions (pp. 27-57). Albany: State University of New York Press.

Côté, S., \& Morgan, L. (2002). A longitudinal analysis of the association between emotion regulation, job satisfaction, and intentions to quit. Journal of Organizational Behavior, 23, 947-962. http://dx.doi.org/10.1002/job.174

Coupland, C., Brown, A., Daniels, K., \& Humphreys, M. (2008). Saying it with feeling: Analysing speakable emotions. Human Relations, 61, 327-353. http://dx.doi.org/10.1177/0018726708088997 
Cropanzano, R., Weiss, H., \& Eliaas, S. (2003). The impact of display rules and emotional labor on psychological well-being at work. In P. Perrewe, \& D. Ganster (Eds.), Emotional and Physiological Processes and Positive Intervention Strategies (Research in Occupational Stress and Well-being, Volume 3 (pp. 45-89). New York: Emerald. http://dx.doi.org/10.1016/S1479-3555(03)03002-6

Denzin, N., \& Lincoln, Y. (2011). The SAGE Handbook of Qualitative Research. London: Sage.

DeVries III, G. T. (2010). Innovations in workplace wellness: Six new tools to enhance programs and maximize employee health and productivity. Compensation \& Benefits Review, 42, 46-51. http://dx.doi.org/10.1177/0886368709346692

Dilorio, J. A., \& Nusbaumer, M. R. (1993). Securing our sanity - anger management among abortion escorts. Journal of Contemporary Ethnography, 21, 411-438. http://dx.doi.org/10.1177/089124193021004001

Dougherty, D., \& Drumheller, K. (2006). Sensemaking and emotions in organizations: Accounting for emotions in a rational(ized) context. Communication Studies, 57, 215-238. http://dx.doi.org/10.1080/10510970600667030

Eckman, P. (1972). Universals and cultural differences in facial expressions of emotion. In J. Cole (Ed.), Nebraska Symposium on Motivation (pp. 207-282). Lincoln: University of Nebraska Press.

Ekman, P. (1993). Facial expression and emotion. American Psychologist, 48, 384-392. http://dx.doi.org/10.1037//0003-066X.48.4.384

Erickson, R. J., \& Wharton, A. S. (1997). Inauthenticity and depression: Assessing the consequences of interactive service work. Work and Occupations, 24, 188-213. http://dx.doi.org/10.1177/0730888497024002004

Evetts, J. (2003). The sociological analysis of professionalism: occupational change in a modern world. International Sociology, 18(2), 395-415. http://dx.doi.org/10.1177/0268580903018002005

Fairclough, N. (2001). Language and Power. London: Pearson Education.

Farrell, A., \& Geist-Martin, P. (2005). Communicating social health: Perceptions of wellness at work. Management Communication Quarterly, 18, 543-592. http://dx.doi.org/10.1177/0893318904273691

Ferrara, K. (2002). Blocking emotions: The face of resistance. In S. Fussell (Ed.), The Verbal Communication of Emotions: Interdisciplinary Perspectives (pp. 224-248). Mahwah: Lawrence Erbaum Associates.

Fiehler, R. (2002). How to do emotions with words: Emotionality in conversations. In S. Fussell (Ed.), The Verbal Communication of Emotions: Interdisciplinary perspectives (pp. 79-106). Mahwah: Lawrence Erbaum Associates.

Fineman, S. (Ed.). (1993). Emotion in organizations. London: Sage.

Forey, G. (2009). Projecting clauses: Interpersonal realisation of control and power in workplace texts. In G. Forey, \& G. Thompson (Eds.), Text Type and Texture (pp. 151-174). London: Equinox.

Foucault, M. (1972). Archaeology of Knowledge. New York: Routledge. http://dx.doi.org/10.1177/053901847000900108

Foucault, M. (1979). Discipline and Punish: The Birth of the Prison. New York: Vintage.

Foucault, M. (1980). Power/Knowledge: Selected Interviews and Other Writings 1972-1977. London: Harvester.

Foucault, M. (1982). Critical Inquiry. Vol. 8, No. 4. Chicago: The University of Chicago Press. http://dx.doi.org/10.1086/448181

Foucault, M. (1988). Politics, Philosophy, and Culture: Interviews and Other Writings, 1977-1984, edited by M. Morris and P. Patton. New York: Routledge.

Foucault, M., Martin, L., Gutman, H., \& Hutton, P. (1988). Technologies of the self: A seminar with Michel Foucault. Boston: University of Massachusetts Press.

Fournier, V. (1999). The appeal to "professionalism" as a disciplinary mechanism. The Sociological Review, 47(2), 280-307. http://dx.doi.org/10.1111/1467-954X.00173

Gibson, D. E. (2006). Emotional episodes at work: An experiential exercise in feeling and expressing emotions. Journal of Management Education, 30, 477-500. http://dx.doi.org/10.1177/1052562905282016

Grandey, A. (2008). Emotions at work: A review and research agenda. In C. Cooper, \& J. Barling (Eds.), Handbook of Organizational Behavior. London: Sage. http://dx.doi.org/10.4135/9781849200448.n14 
Gross, J. (1998). The emerging field of emotion regulation: An integrative review. Review of General Psychology, 2, 271-299. http://dx.doi.org/10.1037//1089-2680.2.3.271

Gross, J. (2002). Emotion regulation: Affective, cognitive, and social consequences. Psychophysiology, 39, 281-291. http://dx.doi.org/10.1017/S0048577201393198

Gross, J., \& Levenson, R. (1997). Hiding feelings: The acute effects of inhibiting negative and positive emotion. Journal of Abnormal Psychology, 106, 95-103. http://dx.doi.org/10.1037//0021-843X.106.1.95

Harré, R. (1986). The Social Construction of Emotions. Oxford: Basil Blackwell.

Hochschild, A. R. (1983). The managed heart. Berkeley: University of California Press.

Hood, S., \& Forey, G. (2008). The interpersonal dynamics of call-centre interactions: Co-constructing the rise and fall of emotions. Discourse \& Communication, 2, 389-409. http://dx.doi.org/10.1177/1750481308095937

Hood, S., \&. Forey, G. (2008). The interpersonal dynamics of call-centre interactions: Co-constructing the rise and fall of emotion. Discourse and Communication, 2(4), 389-409. http://dx.doi.org/10.1177/1750481308095937

Hughes, J. (2005). Bringing emotion to work: Emotional intelligence, employee resistance and the reinvention of character. Work, employment, and society, 19, 603-625. http://dx.doi.org/10.1177\%2F0950017005055675

Kramer, M., \& Hess, J. (2002). Communication rules for the display of emotions in organizational settings. Management Communication Quarterly, 16, 66-81. http://dx.doi.org/10.1177/0893318902161003

Lee, J., \& Jablin, F. M. (1995). Maintenance communication in superior subordinate work relationships. Human Communication Research, 22, 220-257. http://dx.doi.org/10.1111/j.1468-2958.1995.tb00367.x

Lupton, D. (1992). Discourse analysis: A new method for understanding the ideologies of health and illness. Australian Journal of Public Health, 16, 145-150.

Lutgen-Sandvik, P. (2006). Take this job and...: Quitting and other forms of resistance to workplace bullying. Communication Monographs, 73, 406-433. http://dx.doi.org/10.1080/03637750601024156

Majid, A. (2012). Current Emotion Research in the Language Sciences. Emotion Review, 4, 432-443. http://dx.doi.org/10.1177/1754073912445827

Martin, J. (2004). Mourning: How we get aligned. Discourse \& Society, 15, 321-344. http://dx.doi.org/10.1177/0957926504041022

Martin, J., \& White, P. R. (2005). The Language of Evaluation, Appraisal in English. New York: Palgrave Macmillan.

Maslow, H. (1948). "Higher" and "Lower" Needs. Journal of Psychology, 25, 433-436. http://dx.doi.org/10.1080/00223980.1948.9917386

Mayer, N. D., \& Tormala, Z. L. (2010). "Think" versus "feel" framing effects in persuasion. Personality and Social Psychology Bulletin, 36, 443-454. http://dx.doi.org/10.1177/0146167210362981

Muraven, M., Tice, D., \& Baumeister, R. (1998). Self-control as a limited resource: Regulatory depletion patterns. $\begin{array}{llllll}\text { Journal of Personality and Sty-789. } & \text { Pocial Pychology, }\end{array}$ http://dx.doi.org/10.1037//0022-3514.74.3.774

Pearson, C., Andersson, L., \& Porath, C. (2000). Assessing and attacking workplace incivility. Organizational Dynamics, 29, 123-137. http://dx.doi.org/10.1016/S0090-2616(00)00019-X

Pennebaker, J. W. (2003). The social, linguistic and health consequences of emotional disclosure. In J. Suls, \& K. A. Wallston (Eds.), Social psychological foundations of health and illness (pp. 288-313). Malden, MA: Blackwell. http://dx.doi.org/10.1002/9780470753552.ch11

Pennebaker, J. W., Mehl, M. R., \& Niederhoffer, K. G. (2003). Psychological aspects of natural language use: Our words, our selves. Annual Review of Psychology, 54, 547-577. http://dx.doi.org/10.1146/annurev.psych.54.101601.145041

Pennebaker, J. W., Zech, E., \& Rime, B. (2001). Disclosing and sharing emotion: Psychological, social, and health consequences. In M. S. Stroebe, \& R. O. Hansson (Eds.), Handbook of bereavement research: Consequences, copying, and care (pp. 517-543). Washington, DC: American Psychological Association. http://dx.doi.org/10.1037/10436-022 
Pierce, J. (1995). Gender trials: Emotional lives in contemporary law firms. Berkeley, CA: University of Berkeley Press.

Potter, J., \& Wetherell, M. (1987). Discourse and social psychology: Beyond attitudes and behaviour. London: SAGE.

Putnam, L. L., \& Mumby, D. K. (1993). Organizations, emotion and the myth of rationality. In S. Fineman (Ed.), Emotion in organizations (pp. 36-57). Newbury Park, CA: Sage.

Rafaeli, A., \& Sutton, R. I. (1989). The expression of emotion in organizational life. Research in Organizational Behavior, 11, 1-42.

Rimé, B., Corsini, S., \& Herbette, G. (2002). Emotion, verbal expression, and the social sharing of emotion. In S. R. Fussell (Ed.), The verbal communication of emotions: Interdisciplinary perspectives (pp. 185-208). Mahwah, NJ: Erlbaum.

Rubin, H., \& Rubin, I. (2005). Qualitative Interviewing: The Art of Hearing Data. London: Sage.

Sandelands, L. E., \& Boudens, C. J. (2000). Feelings at work. In S. Fineman (Ed.), Emotion in organizations (2nd ed.) (pp. 46-63). London: Sage. http://dx.doi.org/10.4135/9781446219850.n3

Shields, S. A. (2005). The politics of emotion in everyday life: "Appropriate emotion" and claims of identity. Review of General Psychology, 9, 3-15. http://dx.doi.org/10.1037/1089-2680.9.1.3

Shils, E. A. (1970). Deference. In E. O. Laumann, P. M. Seigel, \& R. W. Hodge (Eds.), The logic of social hierarchies (pp. 420-448). Chicago: Markham.

Soley, L., \& Smith, A. (2008). Projective Techniques for Social Science and Business Research. New York: Southshore Press.

Sriram T., Chaturvedi S., Gopinath P., \& Shanmugam V. (1987). Controlled study of alexithymic characteristics in patients with psychogenic pain disorder. Psychotherapy and Psychosomatics, 47(1), 11-17. http://dx.doi.org/10.1159/000287992

Stebbins, A. (2001). Exploratory Research in the Social Sciences. London: Sage.

Stiles, W. (1987). "I have to talk to somebody": A fever model of disclosure. In V. J. Derlega, \& J. H. Berg (Eds.), Self-disclosure: Theory, research, and therapy (pp. 257-282). New York: Plenum Press.

Stiles, W. (1995). Disclosure as a speech act: Is it psychotherapeutic to disclose? In J. Pennebaker (Ed.), Emotion, disclosure, and health (pp. 71-91). Washington, DC: American Psychological Association. http://dx.doi.org/10.1037/10182-004

Taylor, G., Bagby, R., \& Parker, J. (1997). The relationship between emotional intelligence and alexithymia. Personality and Individual Differences, 30(1), 107-115.

Tiedens, T. (2001). Anger and advancement versus sadness and subjugation: The effect of negative emotion expressions on social status conferral. Journal of Personality and Social Psychology, 80(1), 86-94. http://dx.doi.org/10.1037//0022-3514.80.1.86

Tracy, S. (2000). Becoming a character for commerce: Emotion labor, self-subordination, and discursive construction of identity in a total institution. Management Communication Quarterly, 14, 90-128. http://dx.doi.org/10.1177/0893318900141004

Trethewey, A. (1997). Resistance, identity, and empowerment: A postmodern feminist analysis of clients in a human services organization. Communication Monographs, 64, 281-301. http://dx.doi.org/10.1080/03637759709376425

Van Djik, T. (2001). Critical discourse analysis. In D. Tannen, D. Schiffrin, \& H. Hamilton (Eds.), Handbook of Discourse Analysis (pp. 352-371). Oxford: Blackwell. http://dx.doi.org/10.4135/9780857028020.d7

Van Maanen, J., \& Kunda, G. (1989). Real feelings: Emotional expression and organizational culture. Research in Organizational Behavior, 11, 43-103.

Viswanathan, K. (2008). Health communication. In D. Wolfgang (Ed.), The International Encyclopedia of Communication (pp. 2-8). New York: Blackwell.

Waldron, V. R., \& Krone, K. J. (1991). The experience and expression of emotion in the workplace: A study of a corrections organization. Management Communication Quarterly, 4, 287-309. http://dx.doi.org/10.1177/0893318991004003002 
Wharton, A. S., \& Erickson, R. J. (1993). Managing emotions on the job and at home: Understanding the consequences of multiple emotional roles. Academy of Management Review, 18, 457-486. http://dx.doi.org/10.5465/AMR.1993.9309035147

Willig, C. (2004). Discourse analysis and health psychology. In M. Murray (Ed.), Critical Health Psychology (pp. 155-169). New York, Palgrave.

Wood, L., \& Kroger, P. (2000). Doing Discourse Analysis. Methods for studying action in talk and text. Thousand Oaks: Sage.

Zapf, D. (2002). Emotion work and psychological well-being: A review of the literature and some conceptual considerations. Human Resource Management Review, 12(2), 237-268. http://dx.doi.org/10.1016/S1053-4822(02)00048-7 